\title{
The effects of supplementation with sunflower and soybean oils on the fatty acid profile of milk fat from grazing dairy cows
}

\author{
Oldemiro A. RegO ${ }^{\text {a* }}$, Henrique J.D. Rosa ${ }^{a}$, Paula V. PorTUGAL ${ }^{b}$, \\ Tiago FRANCO ${ }^{\text {a }}$, Carlos M. VOUZELA ${ }^{\text {a }}$, Alfredo E.S. BORBA ${ }^{\mathrm{a}}$, \\ Rui J.B. BESSA ${ }^{\text {b }}$ \\ a Departamento de Ciências Agrárias-CITA-A, Universidade dos Açores, \\ 9701-851 Angra do Heroísmo, Portugal \\ b Departamento de Nutrição Animal, Estação Zootécnica Nacional, Fonte Boa, \\ 2000-763 Santarém, Portugal
}

(Received 30 March 2004; accepted 14 October 2004)

\begin{abstract}
The objective of this study was to observe the effect of supplementation with vegetable oils (VO) on the fatty acid profiles and conjugated linoleic acid (CLA) content of milk fat. Twelve dairy cows in mid lactation fed on pasture were blocked by body weight, milk production and days in lactation and randomly allocated from blocks to 3 treatments repeated in a Latin square design with periods of 28 day duration. The treatments were as follows: cows on pasture supplemented with $5 \mathrm{~kg}$ concentrate per head per day (C), supplemented with $4.5 \mathrm{~kg}$ concentrate $+0.5 \mathrm{~kg}$ sunflower oil per head per day (SFO) and supplemented with $4.5 \mathrm{~kg}$ concentrate $+0.5 \mathrm{~kg}$ soybean oil per head per day (SBO). The animals were grazed as a group and were stocked at 2.5 heads per hectare. The treatments had no effect on milk yield or protein yield and content, but decreased milk fat yield and content $(P<0.05)$. Milk fat from the cows supplemented with $\mathrm{VO}$ had a lower concentration of short and medium chain fatty acids $(P<0.05)$ and a higher concentration of long chain fatty acids $(P<0.05)$. The addition of VO to the diet also resulted in a reduction in saturated and an increase in unsaturated fatty acids of milk fat $(P<0.05)$. The hypercholesterolemic fatty acids in milk fat (i.e. C12:0, C14:0 and C16:0) decreased while the concentration of oleic and linoleic acids increased with $\operatorname{VO}(P<$ $0.05)$. There was no effect on linolenic acid. Finally, the inclusion of VO in the diet increased $(P<$ 0.05 ) the contents in milk fat of the various cis/trans isomers of oleic acid (including trans-vacenic, TVA) and of CLA which increased by $61 \%$.
\end{abstract}

dairy cow / conjugated linoleic acid / fatty acids / pasture / vegetable oils

Résumé - Effet de la supplémentation du régime avec de l'huile de tournesol ou de soja sur la composition en acides gras du lait chez la vache laitière au pâturage. L'objectif de cette étude était d'observer l'effet de la supplémentation du régime en huiles végétales sur le profil des acides gras et la teneur en acide linoléique conjugué (CLA) dans les matières grasses du lait. Douze vaches laitières, en milieu de lactation et au pâturage, ont été mises en lot selon le poids vif, la production

\footnotetext{
* Corresponding author: orego@angra.uac.pt
} 
laitière et le stade de lactation. Elles ont été réparties au hasard en lots, et trois traitements ont été testés selon un dispositif en carré latin $3 \times 3$ sur des périodes de 28 jours. Les traitements ont été les suivants: vaches au pâturage supplémentées avec $5 \mathrm{~kg}$ de concentré par bovin par jour (C), supplémentées avec $4,5 \mathrm{~kg}$ de concentré $+0,5 \mathrm{~kg}$ d'huile de tournesol (SFO) et supplémentées avec $4,5 \mathrm{~kg}$ de concentré $+0,5 \mathrm{~kg}$ d'huile de soja (SBO). Les animaux ont été conduits en groupe avec un chargement de 2,5 bovins à l'hectare. La supplémentation n'a eu aucun effet sur la production de lait, de protéines et le taux protéique du lait. En revanche, elle a significativement diminué la production de matières grasses et le taux butyreux du lait $(P<0,05)$. L'addition d'huiles végétales a eu pour conséquence une diminution de la teneur en acides gras à chaîne courte et moyenne $(P<$ $0,05)$ et une augmentation de la teneur en acides gras à chaîne longue $(P<0,05)$ du lait. Elle a également eu pour résultat une réduction de la teneur en acides gras saturés et une augmentation de la teneur en acides gras insaturés $(P<0,05)$. La fraction hypercholestérolémiante des matières grasses du lait (i.e. C12:0, C14:0 et C16:0) a diminué significativement tandis que la concentration en acide oléique et linoléique a augmenté significativement avec les huiles végétales. Aucun effet n'a été observé sur l'acide linolénique. Enfin, l'addition d'huiles végétales dans le régime alimentaire a augmenté significativement $(P<0,05)$ les teneurs des isomères cis/trans de l'acide oléique (y compris le trans-vaccénique) et du CLA qui a augmenté de $61 \%$.

vache laitière / pâturage / huiles végétales / acide gras / acide linoléique conjugué

\section{INTRODUCTION}

Animal and vegetable fat and oils have long been added to animal food concentrates in order to increase the energetic value of the diet, allowing high productive dairy cows to express their productive potential mainly during early lactation. More recently, the main objective of the inclusion of unsaturated lipids in dairy cow diets has been the modification of the fatty acid (FA) profile of milk fat, so as to enhance the nutritive, dietetic and physical characteristics of milk. The aim is to decrease the hypercholesterolemic fraction of milk fat (i.e. saturated FA of medium chain) and increase the unsaturated FA as well as other specific components of milk fat such as conjugated linoleic acid (CLA) and omega n-3, by manipulating the diet of the dairy cow, thus contributing to the improvement of the public image of this animal product [3, 4].

Edible fat from ruminants is the main source of rumenic acid (cis 9 , trans $11-\mathrm{C}_{18: 2}$ ) of the human diet. Rumenic acid is the main CLA isomer which is produced by some rumen bacteria from dietary linoleic acid (LA) present in the diet and also by the $\Delta^{9}$ desaturase enzyme from trans-vaccenic acid (trans 11-C $18: 1$-TVA) present in animals and human tissues $[8,14]$. TVA is also produced in large quantities in the rumen by biohydrogenation of dietary linoleic and linolenic acids [8]. Biological properties of CLA are presently under intensive research because of CLA's potent anticarcinogenic effects and also because of its effects on the immune system, cellular differentiation and on lipid metabolism [3].

In a recent study, Rego et al. [12] compared the profiles of FA in milk fat of cows fed pasture with cows fed a mixture of maize silage and concentrate and observed that the milk produced in pasture was substantially lower in medium and short chain saturated FA and richer in long chain unsaturated FA, CLA, TVA and omega n-3. The enrichment of ruminant products with CLA is currently achieved by increasing the supply of linoleic and linolenic acids in reticulorumen metabolism. Recently, Schroeder et al. [17] emphasized that there is limited research examining the effects of an increased supply of unsaturated long-chain FA through fat supplementation of grazing dairy cows on FA profile and milk CLA concentration.

The objective of the present study was to measure the effects of supplementing dairy cows on pasture with sunflower and soybean oils (good sources of linoleic acid for 
the synthesis of CLA) on animal performance and the profile of fatty acids in the cow's milk fat.

\section{MATERIALS AND METHODS}

Twelve multiparous Holstein dairy cows fed on pasture were blocked by live weight $(536 \pm 46 \mathrm{~kg})$, days in lactation $(110 \pm$ 38 days) and daily milk production $(27.0+$ $3.8 \mathrm{~kg}$ milk per day) and randomly allocated from block to the following treatments: pasture supplemented with $5.0 \mathrm{~kg}$ concentrate per head per day $(\mathrm{C})$; pasture supplemented with $4.5 \mathrm{~kg}$ concentrate $+0.5 \mathrm{~kg}$ sunflower oil per head per day (SFO) and pasture supplemented with $4.5 \mathrm{~kg}$ concentrate $+0.5 \mathrm{~kg}$ soybean oil per head per day (SBO). The treatments were imposed in a Latin square designi.e. 3 groups of 4 cows $\times 3$ treatments $\times$ 3 periods of 28 day duration. The animals were allowed a 21-day period for habituation followed by a period of 7 days for milk yield data collection. The cows were weighed on two consecutive days following a.m. milking at the end of each period. The stocking rate was 2.5 cows $\cdot \mathrm{ha}^{-1}$ on a pasture composed of ryegrass and Poa pratensis allocated in a rotational grazing system. Twenty plucked samples per hectare of pasture were randomly taken daily over the last 7 days of each period and mixed in order to obtain a composite sample. A similar procedure was applied to obtain concentrate samples. The cows received $2.5 \mathrm{~kg}$ of concentrate twice per day in the milking parlour. The ingredient composition $\left(\mathrm{g} \cdot 100 \mathrm{~g}^{-1}\right.$ fresh weight) of the concentrate was barley (40), maize (40), soybean meal (15) and mineral and vitamin premix (5). In the concentrates SFO and SBO, $10 \mathrm{~g}$ of oil was substituted for $10 \mathrm{~g}$ of cereals. On the last day of each period, a sample of milk of two consecutive milkings was collected from all cows in order to determine the fat and protein content by automated infrared analysis using a Milkoscan 605 (Foss Electric, Hillerod, Denmark) and establish the profile of fatty acids.
Chemical analysis of feeds was performed according to the AOAC [1] procedure and the methods of Robertson and Van Soest [13] were used to determine the cell wall components, i.e. neutral detergent fibre (NDF), acid detergent fibre (ADF) and acid detergent lignin (ADL). To determine the FA in the feed, the samples were weighed into a culture tube, and FA methyl esters (FAME) were prepared by the one-step extraction-methylation method of Sukhija and Palmquist [19]. Quantification of FA was done using $4 \mathrm{mg}$ of C17:0 as the internal standard. To determine the FA in milk, samples were lyophilised and $125 \mathrm{mg}$ of dry solids were extracted by chloroform:methanol (2:1) according to Folch et al. [6]. After lipid extraction and evaporation of the solvents by nitrogen flow in a $30^{\circ} \mathrm{C}$ dry bath, FAME were prepared by alkaline transesterification according to Christie [5]. FAME were analysed by GC, using a 100 -m fused silica capillary column CP Sil 88 (Chrompack CP 7489) with $0.25-\mathrm{mm}$ internal diameter and 0.20-mm film thickness. An HP5890A series II chromatograph (Hewlett-Packard, Avondale, PA, USA) working with helium as the carrier gas and a flame ionisation detector was used. The initial column temperature of $130{ }^{\circ} \mathrm{C}$ was held for $20 \mathrm{~min}$, increased to $165^{\circ} \mathrm{C}$ at a rate of $3{ }^{\circ} \mathrm{C}$ per min and held for $35 \mathrm{~min}$. Then, the temperature was increased to $180^{\circ} \mathrm{C}$ at a rate of $2{ }^{\circ} \mathrm{C}$ per $\mathrm{min}$ and held for $25 \mathrm{~min}$. The last ramp was increased with a rate of $1.5{ }^{\circ} \mathrm{C}$ per min to $200{ }^{\circ} \mathrm{C}$, at which it was maintained for $50 \mathrm{~min}$. The injector and detector temperatures were $250^{\circ} \mathrm{C}$ and $280^{\circ} \mathrm{C}$, respectively. Peak identification was based on co-chromatography with known standards of FAME (Sigma, St. Louis, USA). The CLA was computed as the major peak in conjugated octadecadienoic region of the chromatogram that had an elution time consistent with cis-9, trans-11 octadecadienoic FAME (Sigma, St. Louis, USA). The methodology used did not discriminate between the different CLA isomers, however it is well established that the cis-9, trans-11 isomer accounts for more than $90 \%$ of the total in milk fat [4]. 
Table I. Chemical composition and fatty acid content of feeds and vegetable oils.

\begin{tabular}{lcccccc}
\hline FAs & $\mathrm{P}$ & $\mathrm{C}$ & CSFO & CSBO & SFO & SBO \\
\hline Chemical Composition $\left(\mathrm{g} \cdot \mathrm{kg}^{-1} \mathrm{DM}\right)$ & & & & & & \\
Ash & 94 & 58 & 56 & 55 & - & - \\
Crude protein & 184 & 162 & 158 & 159 & - & - \\
Crude fat & 30 & 30 & 123 & 124 & - & - \\
$\mathrm{NDF}$ & 528 & - & - & - & - & - \\
$\mathrm{ADF}$ & 256 & 73 & 69 & 70 & - & - \\
$\mathrm{ADL}$ & 26 & - & - & - & - & - \\
FA $\left(\mathrm{g} \cdot 100 \mathrm{~g}^{-1} \mathrm{FA}\right)$ & & & & & & \\
$\mathrm{C}_{14: 0}$ & 13.07 & 2.21 & 0.65 & 0.55 & - & - \\
$\mathrm{C}_{16: 0}$ & 9.02 & 15.36 & 7.75 & 11.15 & 4.81 & 9.99 \\
$\mathrm{C}_{16: 1}$ & 1.21 & - & - & - & - & - \\
$\mathrm{C}_{18: 0}$ & 1.03 & 2.29 & 2.84 & 2.97 & 3.18 & 3.33 \\
$\mathrm{C}_{18: 1}$ cis-9 & 1.67 & 21.79 & 23.80 & 20.78 & 25.42 & 20.91 \\
$\mathrm{C}_{18: 2}$ & 12.35 & 51.50 & 56.90 & 52.88 & 59.82 & 53.90 \\
$\mathrm{C}_{18: 3}$ & 42.28 & 2.83 & 0.91 & 5.82 & 0.19 & 8.27 \\
Others & 13.37 & 2.09 & 3.29 & 2.46 & 4.29 & 1.71 \\
\hline
\end{tabular}

P: pasture; C: concentrate; CSFO: concentrate mix with sunflower oil; CSBO: concentrate mix with soybean oil; SFO: sunflower oil; SBO: soybean oil.

FA were expressed as $\mathrm{g} \cdot 100 \mathrm{~g}^{-1}$ of reported fatty acids. The results were subjected to the GLM procedure of SAS [15] according to the following model: $\mathrm{Y}_{\mathrm{ijk}}=\mu+\mathrm{T}_{\mathrm{I}}+\mathrm{P}_{\mathrm{j}}+$ $\mathrm{A}_{\mathrm{k}}+\varepsilon_{\mathrm{ijk}}$, where $\mathrm{Y}_{\mathrm{ijk}}$ is the dependent variable, $\mu$ is the global mean, $T$ is the treatment effect, $\mathrm{P}$ is the period effect, $\mathrm{A}$ is the animal effect and $\varepsilon_{\mathrm{ijk}}$ is the residual error. ANOVA did not detect any significant effect of square, its interaction with treatments and cows within the square. Therefore these effects were dropped from the model. The values presented are least squares means followed by standard error of mean (SEM).

\section{RESULTS AND DISCUSSION}

Chemical composition and fatty acid contents of feeds and vegetable oils are presented in Table I. It can be seen that the concentrate and both vegetable oils are good sources of oleic and linoleic acid while the pasture is rich in linolenic acid.
The effect of dairy cow supplementation with lipids on animal performance and on milk fat FA profile is highly variable depending upon the origin of the lipids (animal vs. vegetable), the degree of saturation, efficiency of lipid protection from rumen microbial attack and in the particular case of vegetable sources, the nature of the product i.e. free oil or treated or untreated oleaginous seeds.

Treatments had no effect on milk yield, protein yield and content, but decreased significantly milk fat yield and content $(P<$ $0.05)$. The mean decrease was $110 \mathrm{~g} \cdot$ day $^{-1}$ and $4.7 \mathrm{~g} \cdot \mathrm{kg}^{-1}$ respectively (Tab. II). Live weight was not significantly affected by treatments, but increased $(P<0.05)$ along the experiment. Mean daily live weight gain was $0.48 \mathrm{~kg}$.

According to the review of Schroeder et al. [17] examining data from experiments involving grazing dairy cows supplemented 
Table II. The effect of including sunflower and soybean oils in the concentrate feed with pasture on animal performance.

\begin{tabular}{lcccc}
\hline & C & SFO & SBO & SEM \\
\hline Milk Production $\left(\mathrm{kg} \cdot \mathrm{d}^{-1}\right)$ & 25.9 & 26.2 & 26.3 & 0.29 \\
Fat Content $\left(\mathrm{g} \cdot \mathrm{kg}^{-1}\right)$ & $39.2^{\mathrm{a}}$ & $34.1^{\mathrm{b}}$ & $34.9^{\mathrm{b}}$ & 0.44 \\
Fat Production $\left(\mathrm{g} \cdot \mathrm{d}^{-1}\right)$ & $1015^{\mathrm{a}}$ & $893^{\mathrm{b}}$ & $918^{\mathrm{b}}$ & 13.18 \\
Protein Content $\left(\mathrm{g} \cdot \mathrm{kg}^{-1}\right)$ & 32.9 & 33.0 & 32.9 & 0.26 \\
Protein Production $\left(\mathrm{g} \cdot \mathrm{d}^{-1}\right)$ & 852 & 865 & 865 & 5.56 \\
Live Weight $(\mathrm{kg})$ & 573 & 571 & 574 & 4.29 \\
\hline
\end{tabular}

Means in the same row with different superscripts are significantly different $(P<0.05)$;

C: control; SFO: sunflower oil; SBO: soybean oil; SEM: standard error of mean.

with unsaturated FA, milk yield increased by $3.9 \%$, milk fat content and yield decreased by $8.0 \%$ and $3.8 \%$ respectively, and milk protein content decreased by $3.2 \%$. The results of the present study, concerning the effect of treatments upon milk production and composition, confirm in part the data reported by Schroeder et al. [17] since the inclusion of unsaturated FA in grazing dairy cow diets had a significant effect on milk fat production and content.

The results relating to the effect of vegetable oils (VO) upon the profile of fatty acids of milk fat are presented in Table III. There was no significant difference between the two sources of VO (i.e. sunflower or soybean) on the concentrations of the different fatty acids in milk fat. The inclusion of both oils in the diets resulted in decreases $(P<0.05)$ in the sum of saturated FA $(16 \%)$, short chain FA (35\%), medium FA (20\%) and in the hypercholesterolemic FA fraction $\left(\mathrm{C}_{12: 0}, \mathrm{C}_{14: 0}\right.$ and $\left.\mathrm{C}_{16: 0} ; 22 \%\right)$ and increases $(P<0.05)$ in the sum of unsaturated FA (26\%), long chain FA (22\%), oleic acid (20\%), linoleic acid (23\%), TVA (25\%) and CLA (61\%). Supplementary oils did not significantly influence the concentration of linolenic acid in milk fat. The concentration of oleic acid and its different cis/trans isomers (including trans-10 $\mathrm{C}_{18: 1}$ ) significantly $(P<0.05)$ increased in the milk fat of cows supplemented with VO as a likely consequence of the rumen biohydrogena- tion process of linoleic and linolenic FA present in the diet and due to the desaturation of stearic acid in the mammary gland [4]. These results are globally supported by data reviewed by Schroeder et al. [17] and by the works of Murphy et al. [11], Lawless et al. [9], Vidaurreta et al. [20] and Schroeder et al. [16], leaving cows feeding on pasture. All these authors used oleaginous seeds treated or not, or calcium salts of fatty acids (CaFA), which provide a reduced degree of protection of long chain unsaturated fatty acids to the biohydrogenation in the rumen. Long chain unsaturated fatty acids present in the diet or originating from the mobilisation of body reserves exert a potent inhibitor effect on the synthesis de novo at the mammary gland, responsible for the decrease of the synthesis of short chain FA and to a lower extent of medium chain FA [2]. Another factor that exerts an effect on the de novo synthesis is the action of unsaturated lipids in the diet on the rumen ratio of acetate/propionate [7]. Despite the fact that the oils used in this study were good sources of linoleic acid, its increase in milk fat of supplemented cows, though statistically significant $(P<0.05)$, was low, suggesting a modest transfer efficiency of this fatty acid from vegetable oils to milk fat and a high rate of rumen biohydrogenation. Using fullfat rapeseeds (FFS), full-fat soybeans (FFR) or CaFA which provide some protection from rumen biohydrogenation, other authors 
Table III. The effect of feed supplementation with sunflower and soybean oils on the fatty acid profile of milk fat ( $\left.\mathrm{g} \cdot 100 \mathrm{~g}^{-1} \mathrm{FA}\right)$.

\begin{tabular}{|c|c|c|c|c|}
\hline Fatty Acids & $\mathrm{C}$ & SFO & SBO & SEM \\
\hline $\mathrm{C}_{6: 0}$ & $1.49^{\mathrm{a}}$ & $1.09^{\mathrm{b}}$ & $1.08^{\mathrm{b}}$ & 0.03 \\
\hline $\mathrm{C}_{8: 0}$ & $0.89^{\mathrm{a}}$ & $0.56^{\mathrm{b}}$ & $0.55^{\mathrm{b}}$ & 0.02 \\
\hline $\mathrm{C}_{10: 0}$ & $1.99^{\mathrm{a}}$ & $1.21^{\mathrm{b}}$ & $1.20^{\mathrm{b}}$ & 0.05 \\
\hline $\mathrm{C}_{12: 0}$ & $2.43^{\mathrm{a}}$ & $1.60^{\mathrm{b}}$ & $1.59^{\mathrm{b}}$ & 0.06 \\
\hline Iso $C_{14: 0}$ & 4.64 & 4.24 & 4.09 & 0.37 \\
\hline $\mathrm{C}_{14: 0}$ & $9.63^{\mathrm{a}}$ & $7.02^{\mathrm{b}}$ & $7.09^{\mathrm{b}}$ & 0.17 \\
\hline Iso $\mathrm{C}_{15: 0}$ & $0.30^{\mathrm{a}}$ & $0.22^{\mathrm{b}}$ & $0.22^{\mathrm{b}}$ & 0.006 \\
\hline Anteiso $\mathrm{C}_{15: 0}$ & $0.61^{\mathrm{a}}$ & $0.51^{\mathrm{b}}$ & $0.49^{\mathrm{b}}$ & 0.02 \\
\hline $\mathrm{C}_{15: 0}$ & $1.02^{\mathrm{a}}$ & $0.91^{\mathrm{b}}$ & $0.89^{\mathrm{b}}$ & 0.04 \\
\hline $\mathrm{C}_{16: 0}$ & $24.35^{\mathrm{a}}$ & $19.23^{b}$ & $20.51^{b}$ & 0.36 \\
\hline $\mathrm{C}_{16: 1}$ & 1.68 & 1.59 & 1.66 & 0.05 \\
\hline $\mathrm{C}_{17: 0}$ & $0.58^{\mathrm{a}}$ & $0.48^{\mathrm{b}}$ & $0.49^{\mathrm{b}}$ & 0.001 \\
\hline $\mathrm{C}_{17: 1}$ & $0.28^{\mathrm{a}}$ & $0.20^{\mathrm{b}}$ & $0.21^{\mathrm{b}}$ & 0.004 \\
\hline $\mathrm{C}_{18: 0}$ & 11.86 & 12.71 & 12.49 & 0.27 \\
\hline $\mathrm{C}_{18: 1}$ trans $6+$ trans 8 & 0.37 & 0.52 & 0.64 & 0.08 \\
\hline trans 9 & $0.27^{\mathrm{a}}$ & $0.60^{\mathrm{b}}$ & $0.57^{\mathrm{b}}$ & 0.04 \\
\hline trans 10 & $0.59^{\mathrm{a}}$ & $1.33^{\mathrm{b}}$ & $1.47^{\mathrm{b}}$ & 0.12 \\
\hline trans 11 (TVA) & $2.40^{\mathrm{a}}$ & $2.80^{\mathrm{ab}}$ & $3.18^{\mathrm{b}}$ & 0.21 \\
\hline trans 12 & $0.43^{\mathrm{a}}$ & $1.40^{\mathrm{b}}$ & $1.08^{\mathrm{ab}}$ & 0.23 \\
\hline cis-9 & $22.87^{\mathrm{a}}$ & $27.62^{b}$ & $27.04^{b}$ & 0.34 \\
\hline cis 12 & $0.39^{\mathrm{a}}$ & $0.42^{\mathrm{ab}}$ & $0.46^{\mathrm{b}}$ & 0.01 \\
\hline cis 13 & $0.21^{\mathrm{a}}$ & $0.66^{\mathrm{b}}$ & $0.59^{\mathrm{b}}$ & 0.04 \\
\hline$C_{18: 2} n-6$ & $1.62^{\mathrm{a}}$ & $2.05^{\mathrm{b}}$ & $1.94^{\mathrm{b}}$ & 0.05 \\
\hline CLA & $1.26^{\mathrm{a}}$ & $2.12^{\mathrm{b}}$ & $1.93^{\mathrm{b}}$ & 0.08 \\
\hline$C_{18: 3} n-3$ & 0.71 & 0.63 & 0.67 & 0.04 \\
\hline Others & 6.34 & 7.42 & 6.96 & 0.40 \\
\hline SCFA $\left(\mathrm{C}_{4: 0}\right.$ to $\left.\mathrm{C}_{12: 0}\right)$ & $7.06^{\mathrm{a}}$ & $4.61^{\mathrm{b}}$ & $4.57^{\mathrm{b}}$ & 0.18 \\
\hline MCFA (C $14: 0$ to $\left.C_{17: 1}\right)$ & $43.03^{\mathrm{a}}$ & $34.40^{\mathrm{b}}$ & $35.65^{\mathrm{b}}$ & 0.43 \\
\hline LCFA $\left(\geq \mathrm{C}_{18: 0}\right)$ & $43.54^{\mathrm{a}}$ & $53.61^{\mathrm{b}}$ & $52.81^{\mathrm{b}}$ & 0.52 \\
\hline Hypercholesterolemic FA & $36.41^{\mathrm{a}}$ & $27.84^{\mathrm{b}}$ & $29.19^{\mathrm{b}}$ & 0.29 \\
\hline SFA & $59.97^{\mathrm{a}}$ & $49.95^{b}$ & $50.88^{\mathrm{b}}$ & 0.47 \\
\hline UFA & $33.66^{\mathrm{a}}$ & $42.67^{\mathrm{b}}$ & $42.15^{b}$ & 0.34 \\
\hline
\end{tabular}

C: control; SFO: sunflower oil; SBO: soybean oil; SEM: standard error of mean; SCFA: short chain fatty acids; MCFA: medium chain fatty acids; LCFA: long chain fatty acids; Hypercholesterolemic FA (sum of $\mathrm{C}_{12: 0}, \mathrm{C}_{14: 0}, \mathrm{C}_{16: 0}$ ); SFA: saturated fatty acids; UFA: unsaturated fatty acids; Means in the same row with different superscript are significantly different $(P<0.05)$. 
observed a two fold increase in linoleic acid concentration in milk fat of grazed cows $\left(4.9 \mathrm{~g} \cdot 100 \mathrm{~g}^{-1} \mathrm{FA}\right)[9,11,16]$. Unlike what happens with diets composed of conserved forage and variable proportions of concentrates, there is less information in the literature concerning the effect of oils or vegetable seed supplementation of diets on the concentrations of CLA and TVA in the milk fat of grazing dairy cows. Stanton et al. [18] and Lawless et al. [9] reported significant increases in the concentrations of CLA and TVA in the milk fat of grazing cows directly related to the amount of FFS and FFR supplemented, which were supported by the results of the present study. Partially replacing maize grain by $\mathrm{CaFA}$ in the concentrate supplemented to grazing dairy cows, increased the CLA content in milk fat by $58 \%$ [20] and by $173 \%$ [16]. The oil source, despite a slight difference in FA composition, did not significantly influence the CLA content of milk fat (Tab. III). It seems that the difference in the FA profile of the two oils did not influence the rumen biohydrogenation pattern. Kelly et al. [10] reported that oils rich in linoleic acid (sunflower) were more efficient than oleic or linolenic sources in increasing the CLA content of milk fat. In contrast, Lawless et al. [9] found that FFR (oleic acid) were more efficient than FFS (linoleic acid).

\section{CONCLUSIONS}

The supplementation of grazing dairy cow diets with rations incorporating vegetable oils had a marked effect upon the profile of fatty acids of milk fat. The concentration of the hypercholesterolemic fraction of milk fat decreased as the concentration of the desirable constituents like mono and polyunsaturated FA (including CLA and TVA) increased, with no negative effect on milk production or on protein content. This change in the fatty acid profile of milk fat can contribute to an improvement of the dietetic quality of milk and of its image as perceived by the consumer.

\section{REFERENCES}

[1] AOAC (Association of Official Analytical Chemists), Official Methods of Analysis, 15th ed., AOAC, Arlington, VA, 1990.

[2] Barber M.C., Clegg R.A., Travers M.T., Vernon R.G., Lipid metabolism in the lactating mammary gland, Biochem. Biophys. Acta 1347 (1997) 101-126.

[3] Bessa R.J.B., Santos-Silva J., Ribeiro J., Portugal A.V., Reticulo-rumen biohydrogenation and the enrichment of ruminant edible products with linoleic acid conjugated isomers, Livest. Prod. Sci. 63 (2000) 201-211.

[4] Chilliard Y., Ferlay A., Doreau M., Effect of different types of forages, animal fat or marine oils in cow's diet on milk fat secretion and composition, especially conjugated linoleic acid and polyunsaturated fatty acids, Livest. Prod. Sci. 70 (2001) 31-48.

[5] Christie W.W., The preparation of derivates of fatty acids. Gas chromatography and lipids - a practical guide, The Oily Press, Glasgow, Scotland, UK, 1994, pp. 64-84.

[6] Folch J., Lees M., Sloane G.H., A simple method for the isolation and purification of total lipids from animal tissues, J. Biol. Chem. 226 (1957) 497-509.

[7] Doreau M., Chilliard Y., Rulquin H., Demeyer D.I., Manipulation of milk fat in dairy cows, in: Garnsworthy P.C., Wiseman J. (Eds.), Recent Advances in Animal Nutrition, Nottingham University Press, Nottingham, 1999, pp. 81-109.

[8] Griinari J.M., Bauman D.E., Biosynthesis of conjugated linoleic acid and its incorporation into meat and milk in ruminants, in: Yurawecz M.P., Mossoba M.M., Kramer J.K.G., Nelson G., Pariza M.W. (Eds.), Advances in Conjugated Linoleic Acid Research, Vol. 1, AOCS Press, Champaign, 1999, pp.180-200.

[9] Lawless F., Murphy J.J., Harrington D., Devery R., Stanton C., Elevation of conjugated cis-9, trans-11 octadecadienoic acid in bovine milk because of dietary supplementation, J. Dairy Sci. 81 (1998) 3259-3267.

[10] Kelly M.L., Berry J.R., Dwyer D.A., Griinari J.M., Chouinard P.Y., Van Amburgh M.E., Bauman D.E., Dietary fatty acid sources affect conjugated linoleic acid concentrations in milk fat from lactating dairy cows, J. Nutr. 128 (1998) 881-885

[11] Murphy J.J., Connolly J.F., McNeil G.P., Effects of cow performance and milk fat composition of feeding full fat soybeans and rapeseeds to dairy cows at pasture, Livest. Prod. Sci. 44 (1995) 13-25. 
[12] Rego O.A., Portugal P.V., Sousa M.B., Rosa H.J.D., Vouzela C.M., Borba A.E.S., Bessa R.J.B., Effect of diet on the fatty acid pattern of milk from dairy cows, Anim. Res. 53 (2004) 213-220.

[13] Robertson J.B., Van Soest P.J., The detergent system of analysis and its application to human foods, in: James W.P.T., Theander O. (Eds.), The Analysis of Dietary Fiber in Food, Marcel Dekker, New York, 1981, pp. 123158.

[14] Salminen I.M., Mutanen M., Jauhiaimen M., Aro A., Dietary trans fatty acids increase CLA levels in human serum, J. Nutr. Biochem. 9 (1998) 93-98.

[15] SAS, SAS/STAT User's Guide (Release 6.03), SAS Inst., Cary, NC, USA, 1988.

[16] Schroeder G.F., Delahoy J.E., Vidaurreta I.I., Bargo F., Gagliostro G.A., Muller L.D., Milk fatty acid composition of cows fed a total mixed ration or pasture plus concentrates replacing corn with fat, J. Dairy Sci. 86 (2003) 3237-3248.

[17] Schroeder G.F., Gagliostro G.A., Bargo F., Delahoy J.E., Muller L.D., Effects of fat supplementation on milk production and composition by dairy cows on pasture: a review, Livest. Prod. Sci. 86 (2004) 1-18.

[18] Stanton C., Lawless F., Kjellmer D., Harrington R., Devery R., Connolly J.F., Murphy J.J., Dietary influences on bovine milk cis-9, trans-11-conjugated linoleic acid content, J. Food Sci. 62 (1997) 1083-1086.

[19] Sukhija P.S., Palmquist D.L., Rapid method for determination of total fatty acid content and composition of feedstuffs and faeces, $\mathrm{J}$. Agric. Food Chem. 36 (1988) 1202-1206.

[20] Vidaurreta I.I., Gagliostro G.A., Schroeder G.F., Rodriguez A., Gatti P., Partial replacement of corn grain by calcium salts of unsaturated fatty acids in grazing dairy cows: $2-$ Milk fatty acid composition, J. Dairy Sci. 85 (Abstr.) (2002) 311-312. 